\title{
FACTORS ASSOCIATED TO BASIC EMERGENCY OBSTETRIC NEONATAL CARE (BEONC) NURSES' DECISION MAKING SKILL
}

\author{
Ahsan $^{1}$, Ni Luh Diah Ayu Sita Dewi ${ }^{2}$, Ali Haedar ${ }^{3}$, Ike Nesdia Rahmawati ${ }^{4}$ \\ 1. Department Of Nursing, Medical Faculty Brawijaya University Malang Indonesia \\ 2. Master Of Nursing Student Of Medical Faculty Brawijaya University Malang Indonesia \\ 3. Department Of Medicine, Medical Faculty Brawijaya University Malang Indonesia \\ 4. Department Of Nursing, Medical Faculty Brawijaya University Malang Indonesia
}

\begin{abstract}
Neonatal mortality rate (NMR) is one of indicator to measure population health. The three delays model explains three underlying causes of noenatal mortality, including delay in recognizing emergency condition, reaching health facilities, and receiving treatment. The main cause of delay in recognizing emergency condition is decision making skill of the nurse to determine emergency condition in neonatal. This research aims to analyze influence of age, gender, education level, advance training, working experience, and employment status of nurse to decision-making skill in basic emergency of obstetric and neonatal care (BEONC) at community health care center. This research is analytic correlational study with cross sectional approach. One hundred fifty three BEONC nurses in Malang district were involved in this research. 'Critical Thinking Diagnostic Tool Nursing Executive Center' was used to measure decision making skill. Result showed that age, training, working experience and employment status were not related to decision making skill $(p>0.05)$. While, gender and education background are significantly associated to decision making skill of nurses. It is concluded that gender and educational background of nurse contribute to decision making skill in basic emergency of obstetric and neonatal care. This study gives insight about the importance of improving critical thinking skill through continuing education and gender consideration for nursing staff placement.
\end{abstract}

Keyword : Characteristic, emergency, decision making, neonatal, nurse

\section{ABSTRAK}

Angka kematian neonatal (NMR) merupakan indikator penting untuk menilai derajat kesehatan masyarakat. Keterlambatan mengenali kondisi kegawatan, penundaan mencapai fasilitas kesehatan, keterlambatan menerima penanganan adalah tiga penyebab dasar kematian neonatal menurut model teori "Tiga penundaan kegawatan neonatal". Penyebab utama keterlambatan mengenali kondisi kegawatan adalah kemampuan pengambilan keputusan oleh perawat untuk menentukan kondisi kegawatan pada neonatal. Tujuan penelitian ini menganalisis pengaruh usia, jenis kelamin, tingkat pendidikan, pelatihan lanjut, pengalaman kerja, dan status kepegawaian perawat terhadap kemampuan pengambilan keputusan perawat pada pelayanan obstetri neonatal emergensi dasar (PONED). Penelitian ini adalah penelitian analisis korelasional dengan pendekatan cross sectional. Jumlah subyek penelitian terdiri 153 perawat PONED di Kabupaten Malang. 'Critical Thinking Diagnostic Tool Nursing Executive Center' digunakan untuk mengukur kemampuan pengambilan keputusan. Hasil menunjukan bahwa usia, pelatihan, pengalaman kerja, dan status kepegawaian perawat tidak berhubungan dengan kemampuan pengambilan keputusan. Sementara itu, jenis kelamin dan latar belakang pendidikan berhubungan secara signifikan terhadap kemampuan pengambilan keputusan perawat. Kesimpulan dalam penelitian ini adalah jenis kelamin dan pendidikan perawat berhubungan terhadap kemampuan pengambilan keputusan perawat di PONED. Hasil penelitian ini memberikan wawasan tentang pentingnya meningkatkan kemampuan berpikir kritis melalui pendidikan berkelanjutan dan pertimbangan jenis kelamin pada penempatan tenaga perawat.

Kata Kunci : Karakteristik, kegawatan, pengambilan keputusan, neonatal, perawat 


\section{BACKGROUND}

Mortality neonatal rate in Indonesia in 2000 until 2007 was 19 per 1000 live birth (Unicef, 2012). East java is one of provinces in Indonesia which succeed in decreasing birth rate from 31.41 per 1000 live birth in 2009 to 28.31 per 1000 live birth in 2012. However, it has not achieved target of MDGs yet which is 23 per 1000 per live birth in 2015.

Neonatal mortality rate in Malang district keeps increasing in the last few years. In 2014, the rate reached $6 \%$ from 1047 total case of asphyxia neonatal. In the same year, 7\% from 1496 low birth weight infant died on first 28 days of life. In 2015 , mortality rate of asphyxia neonatal cases increase to 7\% (from total 698 cases) (Report of Public Health Office of Malang Distric, 2016).

About 5-10\% new born babies need help in the process of adaptation from intra-uteri to outside environment (Soraisham, 2013). About $1 \%$ of them need resuscitation to avoid respiratory or heart failure (Biban, 2009). The high number of asphyxia-related death in neonatus is associated to delay in recognizing the signs of emergency, reaching health facilities, and receiving treatment (Manton, 2004).

In 1995, government launched Basic Emergency Obstetric Neonatal Care (BEONC) program. Through this program, it was expected that primary health care facility could increase the quality on maternal and neonatal emergency care (Okoli, 2012). One of standardized basic emergency service is the availability of competent emergency team. Nurses as part of the team should possess decision making skills in emergency condition (Lawn, 2010). Increasing neonatal mortality rate in primary care is associated to delay on decision making in regards to emergency conditions, particularly asphyxia neonatal (Wyllie, 2010). Decision to start initial treatment and integrate referral for neonatal emergency condition should be made in a timely manner (Manton, 2004).

Nurse's decision making skills can be influenced by some factors. Husna (2011) stated that age, gender, educational background, advance education training, and length of work experience are internal factors contribute to nurse's decision making skill. However, employment status has not been known of its' contribution to decision making skill. Moreover, the relationship between these internal factors and nurses' decision making skill in neonatal emergency is unknown.

This study aims to analyse nurses related characteristics contribute to decision making skills in regards to basic emergency obstetric care (BEONC) service at community health center settings.

\section{METHOD}

This research is analytic correlational study with cross sectional approach. Population is 253 nurses of Basic Emergency Obstetric and Neonatal Care (BEONC) at community health center of Malang District. A total of 153 nurses met inclusion and exclusion criteria to be respondents. 'Critical Thinking Diagnostic Tool Nursing Executive Center' was used to measure decision making skill. Data was analyzed used univariate analysis, bivariate test (cross tab), and multivariate analysis (logistic regression). This research had fulfilled all ethical requirements by the ethic committee of Polytechnic of Health the ministry of health Malang.

\section{RESULT}

One hundred fifty three nurses were involved in the study to determine factors associated to BEONC nurses' decision making skill. Their characteristics is shown in table 1. 
Tabel 1. Characteristics of BEONC nurses ( $n=153)$.

\begin{tabular}{lcc}
\hline \multicolumn{1}{c}{ Characteristics of Respondent } & Numbers & Percentage (\%) \\
\hline Age: & & \\
$\quad$ Young adult (21-34 y.o) & 114 & 74,5 \\
$\quad$ Adult (35-60 y.0) & 39 & 25,5 \\
Gender: & 61 & 39,9 \\
$\quad$ Male & 92 & 60,1 \\
$\quad$ Female & & \\
Educational Background: & 141 & 92,2 \\
$\quad$ Nursing Diploma & 12 & 7,8 \\
$\quad$ Bachelor of Nursing Science & & 2,0 \\
Training and Tertiary Education: & 3 & 98,0 \\
$\quad$ Good & 150 & 19,0 \\
$\quad$ Poor & & 81,0 \\
Work Experience: & 29 & 28,8 \\
$\quad$ Nursing Staff (2-3 years) & 124 & 71,2 \\
$\quad$ Advance Clinical Nurses (>3 years) & & \\
Employment Status: & 44 & \\
$\quad$ Civil Servant & 109 & \\
$\quad$ Contract Emplyoyee & &
\end{tabular}

Most of the respondents were young adult, female, nursing diploma graduate. Further, most of them were poor on training and tertiary education, had $>3$ years working experience, and contract nurses.

Tabel 2. Emergency training followed by BEONC nurses $(n=153)$

\begin{tabular}{ccc}
\hline Training & Numbers & Percentage (\%) \\
\hline Type of Training : & 3 & \\
BEONC/PONED & 137 & 2,0 \\
BCLS & 13 & 89,5 \\
BTLS & 1 & 8,5 \\
ACLS & 47 & 0,7 \\
GELS/PPGD & & 30,7 \\
Numbers of Training: & 108 & \\
1 type & 42 & 70,6 \\
2 type & 3 & 27,5 \\
3 type & & 2,0 \\
\hline
\end{tabular}

Table. 2 shows that most of Majority of them have taken more than BEONC nurses had taken BCLS training. one type of emergency training.

Tabel 3. Decision making skill of BEONC nurse $(n=153)$

\begin{tabular}{lcc}
\hline Dependent Variabel & Numbers & Percentage (\%) \\
\hline Decision Making & & \\
Good & 78 & 51,0 \\
Poor & 75 & 49,0 \\
\hline
\end{tabular}

About half of respondents and another half showed poor skill (49\%). showed good decision making skill (51\%) (Table 3). 
Tabel 4. Association between BEONC nurse' characteristics and decision making skill $(n=153)$

\begin{tabular}{|c|c|c|c|c|c|}
\hline \multirow{3}{*}{ Independent Variabel } & \multicolumn{4}{|c|}{ Making Decision Skll } & \multirow[t]{3}{*}{$\mathbf{p}$} \\
\hline & \multicolumn{2}{|c|}{ Good } & \multicolumn{2}{|c|}{ Poor } & \\
\hline & $\mathbf{n}$ & $\%$ & $\mathbf{n}$ & $\%$ & \\
\hline \multicolumn{6}{|l|}{ Age: } \\
\hline Young Adult(21-34 y.o) & 60 & 52,6 & 54 & 47,4 & 0,608 \\
\hline Adult (35-60 y.o) & 18 & 46,2 & 21 & 53,8 & \\
\hline \multicolumn{6}{|l|}{ Gender: } \\
\hline Male & 38 & 62,3 & 23 & 37,7 & 0,034 \\
\hline Female & 40 & 43,5 & 52 & 56,5 & \\
\hline \multicolumn{6}{|l|}{ Educational Background: } \\
\hline Nursing Diploma & 77 & 54,6 & 64 & 45,4 & 0,005 \\
\hline Bachelor of Nursing Science & 1 & 8,3 & 11 & 91,7 & \\
\hline \multicolumn{6}{|l|}{ Training and Tertiary Education: } \\
\hline Good & 2 & 66,7 & 1 & 33,3 & 0,515 \\
\hline Poor & 76 & 50,7 & 74 & 49,3 & \\
\hline \multicolumn{6}{|l|}{ Work Experience: } \\
\hline Nursing Staff (2-3 years) & 11 & 35,5 & 20 & 64,5 & 0,083 \\
\hline Advance Clinical Nurses ( $>3$ tahun) & 67 & 54,9 & 55 & 45,1 & \\
\hline \multicolumn{6}{|l|}{ Employment Status: } \\
\hline Civil Servant & 22 & 50,0 & 22 & 50,0 & 1,000 \\
\hline Contract Employee & 56 & 51,4 & 53 & 48,6 & \\
\hline
\end{tabular}

Bivariat analysis on table 4 including age, training and tertiary eduction, working experience and employment status has no significant

association on decision making skill $(p>0,05)$. Other characteristics, namely gender and educational beckground are significantly associated to decision making skill of BEONC nurses $(p<0,05)$.

Tabel 5. Regression analysis of BEONC nurse characteristics

\begin{tabular}{lcccccc}
\hline & Kof & S.E. & Wald & df & p & OR \\
\hline Gender & $-0,900$ & 0,356 & 6,381 & 1 & 0,012 & 0,407 \\
Educational Background & 2,777 & 1,072 & 6,707 & 1 & 0,010 & 16,064 \\
Constanta & $-2,031$ & 1,058 & 3,685 & 1 & 0,55 & 0,131 \\
\hline
\end{tabular}

Multivariate analysis showed that educational background was the major factor contributing to decision making skill of BEONC nurse (Table 5).

\section{DISCUSSION}

This study aims at identifying characteristics that contribute to decision making skill of BEONC nurses. Result showed that there were no significant relationship between age, training and tertiary eduction, working experience and employment status and decision-making skill of nurses in basic emergency of obstetric and neonatal care. The results of this study are in line with Dehghani (2016) who found that there was no significant relationship between age, marital status, work unit, education, and length of work of nurses with the ability to think critically for problem solving. Critical thinking is known to be an important part for developing efficient communication, improving problems-solving, and understanding the concept of theoretical science in nursing (Akca, 2015). The ability to think critically in decision making is not influenced by age. Older ages do not guarantee that individual has maturity in thinking. Young people who have a lot of knowledge and experience can have better decisionmaking skill than their counterpart.

This study found that gender become one of factors influencing decision-making skill. Male nurses showed better skill than female nurses. However, the strength of the relationship between two variables is weak. This is in line with 
Rodzalan (2015) that found that ability to survive a job with a time limit and introduction of something new in men is better than women. In another study it was also found that problem solving skill of male nurses is better than female nurses (Aboshaiqah, 2014). In handling emergency and critical situation and working with specific time and target pressure, male nurses showed better resilience than female nurses. Skill to determine priority problems and effective interventions should be owned by an emergency and critical nurse.

Another factor that contributes to decision making skill is education background. Level of education of nurses is factor that influences their critical thinking skill. Nurses with bachelor's degree showed better skill to think critically than those with diploma degree. Research by Alghifari (2014) showed that level of competence and curriculum affect motivation of bachelor nursing to think nursing problem critically. After completing basic education, nurses are more often exposed to neonatal emergency conditions and various types of neonatal emergency cases. Those can improve their critical thinking skill (Huchon, 2014). Critical thinking skill should be set as learning outcome in nursing curriculum. Right learning method should be chosen to achieve the outcome, so that nursing graduate would possess the skill (Dehghani, 2016). To create health workers with special neonatal care competencies, it requires access to formal education and special training with comprehensive qualifications and competencies. If it can be achieved, neonatal mortality and morbidity rate can be lowered (Turrill, 2014)

In this study, it was also identified that advance training and tertiary education of nurses did not have a relationship with decision-making skill. Emergency nurses are declared 'competent' in providing treatment for neonatal emergencies if they have attended training related to handling neonatal emergency cases and having minimum of 3 years work experience in emergency unit. Similarly, Pilevarzadeh
(2015) noticed that there was no significant relationship between levels of education and the ability of nurse to think critically. Critical thinking in handling neonatal emergencies can be improved by exposing nurses to various neonatal emergency cases. To develop critical thinking skills in handling neonatal emergencies, role play learning methods based on case study can be employed.

Another factor that also did not show a relationship with decision-making ability in this study is the length of work experience. Most of respondents in this research had worked at the community health center of obstetric neonatal basic emergency service more than three years. Considering the length of work, they can be called as an advanced clinical nurse. However, most of nurses with educational background of nursing diploma had only followed general basic emergency training, which do not cover competence to handle neonatal emergency cases. Nurses who hold bachelor's degree of nurses showed better critical thinking skill. BEONC nurses is not only expected able to provide basic emergency care in neonatal, but also detect causal factors of neonatal emergencies (Brosseau, 2006). Case study-based research from several different cases of neonatal emergencies can be used to improve the critical thinking of nurses (Huchon, 2014).

Employment status in this study was not related to decision making skill of the nurses. Lack of association between two variabels because members of the emergency team own similar legality. Critical thinking skill is taught in basic education of nursing. Similar result was shown in Dehghani (2016). Length of work of nurses was not associated to ability to think critically in problem solving. Critical thinking in problem solving is a dynamic and ongoing process. The process does not stop at basic nursing education, training and advanced education. Individual's action to improve critical thinking and problem solving skill is driven by internal factors such as personal motivation and external factors such as management support and work environment (Akca, 2015). Regarding 
work environment, facilities and equalization system of workload will improve employee's comfort and productivity. Critical thinking skills can also be developed by exposing nurses to emergency handling team, not only by training.

\section{CONCLUSION}

Gender and education background contribute to decision making skills. This study gives new insight about the importance of improving critical thinking skill through continuing education and gender consideration in staff placement.

\section{REFERENCES}

Akca, S. O. \& Selen, F. (2015). Nursing Students' Critical Thinking Levels. The European Proceedings of Social \& Behavioural Sciences, 74-83.

Biban, P., Soffiati, M. \& Santuz P. (2009). Neonatal resuscitation in the ward: The role of nurses. Early Human Development, 85(10 Suppl): S11S13.

doi:10.1016/j.earlhumdev.2009.08.0 04.

Brousseau, T. \& Sharieff, G. Q. (2006). Newborn Emergencies: The First 30 Days of Life. Pediatric Clinics of North America 53(1), 69-84. doi:10.1016/j.pcl.2005.09.011.

Cooper, S., Endacott, R., \& Cant, R. (2010). Measuring non-technical skills in medical emergency care: a review of assessment measures. Open Access Emergency Medicine, 2, 7-16.

Dehghani, H., Dehghani, K., Salami, T., \& Zare, M. H. (2016). Evaluating of Critical thinking in nurses who working in intensive and cardiac care unit. International Journal of Advanced Biotechnology and Research, 7(4), 446-452.

Husna, C., Hatthakit, U., \& Chaowalit, A. (2011). Emergency training, education and perceived clinical skills for tsunami care among nurses in Banda Aceh, Indonesia. Nurse Media Journal of Nursing, 1(1), 7586.

Lawn, J. E., Kerber, K., Enweronu-Laryea, C., \& Cousens, S. (2010). 3.6 Million Neonatal Deaths What Is Progressing and What is Not?. Seminars in Perrnatology. 34(6), 371-386. doi:10.1053/j.semperi.2010.09.011

Okoli, U., Abdullahi, M. J., Pate, M. A., Abubakar, I.S., Aniebue, N., \& West, C. (2012). Clinical Article: Prenatal care and basic emergency obstetric care services provided at primary healthcare facilities in rural Nigeria. International Journal of Gynecology and Obstetrics, 117(1), 61-65. doi:10.1016/j.ijgo.2011.11.014

Maton, Anne. (2004). Emergency Nursing. The Journal of Emergency Nursing. P.25.

Pilevarzadeh, M., Shahrokhi, S., \& Salari, S. (2015). The role of critical thinking in the educational progress of nursing university students. International Journal of Current Research and Academic Review, 3(5), 196-203.

Rodzalan, S. A. \& Saat, M. M. (2015). The Perception of critical thinking and problem solving skill among Malaysian undergraduate students. Procedia Social and Behavioral Sciences, 172, 725-732.

Turrill, S. (2014). The education of UK specialised neonatal nurses: Reviewing the rationale for creating a standard competency framework. Nurse Education in Practice, 14(5), 504-511.

doi:10.1016/j.nepr.2014.07.001

Soraisham, A. S. et al. (2014). Clinical Paper: Neonatal outcomes following extensive cardiopulmonary 
resuscitation in the delivery room for infants born at less than 33 weeks gestational age. Resuscitation, 85(2), 238-243. doi:10.1016/j.resuscitation.2013.10.0 16.

Wyllie, J. et al. (2010). Part 11: Neonatal resuscitation 2010 international consensus on cardiopulmonary resuscitation and emergency cardiovascular care science with treatment recommendations. Circulation, 122(16 Suppl 2), S516538.

doi:10.1161/CIRCULATIONAHA.110 .971127 